\title{
Daniëlle Slootjes
}

\section{Local Elites and Power in the Roman World: Modern Theories and Models}

Roman Imperial Identities in the Early Christian Era. By Judith Perkins (New York, Routledge, 2009) 220 pp. \$I I .00 cloth \$39.95 paper

In recent years, scholars from such fields as sociology and cultural anthropology have attempted to apply modern theories and models to the analyses of local elites in the Roman Empire. Those who take a more traditional and prosopographical approach to these elites bristle at the sacrifice of historical detail that such broad interdisciplinary studies tend to entail, preferring to base their arguments exclusively on close attention to the ancient source material. ${ }^{1}$

Before deciding on what kind of method to apply, any scholar

Daniëlle Slootjes is Assistant Professor of Ancient History, Radboud University. She is the author of The Governor and his Subjects in the Later Roman Empire (Boston, 2006); "Bishops and Their Position of Power in the Late Third Century CE: The Cases of Gregory Thaumaturgus and Paul of Samosata," Journal of Late Antiquity, IV (201 I), IOO-I I s.

(C) 20 I I by the Massachusetts Institute of Technology and The Journal of Interdisciplinary History, Inc.

I For more in-depth discussions about the structure of Roman society and its elites, see Geza Alföldy, Römische Sozialgeschichte (Wiesbaden, I984); Ségolène Demougin, L'ordre équestre sous les Julio-Claudiens (Paris, I988); Friedrich Vittinghof (ed.), Europäische Wirtschaftsund Sozialgeschichte in der römischen Kaiserzeit (Stuttgart, I990); David Potter, The Roman Empire at Bay, A.D. 180-395 (New York, 2004), 66-82. For other recent ideas about elites, see Arethusa, XXXIII (Fall, 200o), which was entirely dedicated to elites, especially in late antiquity. For local elites, see Mireille Cebeillac-Gervasoni and Laurent Lamoine (eds.), Les élites et leurs facettes: les élites locales dans le monde hellénistique et romain (Rome, 2003). Keith Hopkins is a pioneer in the field of ancient history for his early attempts to apply models from sociology and anthropology to the ancient world in, for example, "On the Probable Age Structure of the Roman Population," Population Studies, XX (1966), 245-264; idem, Conquerors and Slaves (New York, I978); idem, Death and Renewal (New York, I983). See also Brent Shaw, "Social Science and Ancient History: Keith Hopkins in Partibus Fidelium," Helios, IX (I982), I9-20, which depicts the traditional approach of modern scholarship about the ancient world as "empirico-positivistic (logico-inductive), causal, and event-specific." Scholars who analyze the ancient economy or the demography of the ancient world are not averse to employing models. See Willem Jongman, The Economy and Society in Ancient Pompeii (Amsterdam, I988); Paul Erdkamp, "Beyond the Limits of the 'Consumer City': A Model of the Urban and Rural Economy in the Roman World," Historia, L (200I), 332-356; Walter Scheidel, "Emperors, Aristocrats, and the Grim Reaper: Towards a Demographic Profile of the Roman Élite," Classical Quarterly, XLIX (I999), 254-28I; idem, "Roman Age Structure: Evidence and Models," Journal of Roman Studies, XVI (200I), I-26. 
offering a study of local elites will have to deal with the problem of terminology and definition. Scholars seem to accept the adequacy of the general term local elite, despite its vagueness in practice: What precisely does local mean in such a context, and who are the individuals who collectively make up the elite? To be sure, city councilors in the Roman Empire would be considered members of the local elite, but what about senators and equites (horsemen or knights) who had local estates and were involved in the functioning of local communities? Were they to be regarded as members of the local elite as well? Senators and city councilors were hardly equals. Furthermore, are the local elites of the bigger cities - such as Athens, Alexandria, or Ephesus - comparable with those in the thousands of smaller ones that were spread throughout the Empire? The top people in Alexandria were not in the same league as those in any of the smaller towns. Regrettably, these issues have not often been taken into consideration in modern studies on local elites in the Roman Empire. ${ }^{2}$

In her examination of "Roman imperial identities," Perkins employs "the term elite to designate a group identity evolving across the empire that united persons from different geographical locations and ethnic backgrounds, with 'power, status and wealth' "(4). Perkins' aim is to examine those people who moved, both physically and mentally, from a "smaller place" to a "larger world" within Empire culture. She focuses on two specific groups, elites and Christians, whose experiences as cosmopolitan trans-Empire social entities can enlarge our understanding of the Empire at large. Perkins' functional definition allows her to group all of those with power, status, and wealth throughout the entire Empire, without apparently having to specify further what power, status, or wealth means. Her definition, therefore, remains a gen-

2 Other terms referring to the same group of people at the local level are "local aristocracy" or "nobility," general and vague terms that need further explanation. See Christian Witschel and Barbara Borg, "Veränderungen im Repräsentationsverhalten der römischen Eliten während des 3. Jhs. n.Chr.," in Alföldy and Silvio Panciera (eds.), Inschriftliche Denkmäler als Medien der Selbstdarstellung in der römischen Welt (Stuttgart, 200I), 62, which discusses the inscriptions for the "gewöhnliche Angehörige der lokalen Oberschicht" but does not identify who these people were, though implying that the local upper classes also contained "ungewöhnliche" members. See also Hubert Devijver, "Local Elite, Equestrians and Senators: A Social History of Roman Sagalassos," Ancient Society, XXVII (I996), I06, where the term "local municipal elite" appears; for the problem of terminology, Clifford Ando, "The Army and the Urban Elite: A Competition for Power," in Erdkamp (ed.), A Companion to the Roman Army (Malden, Mass., 2007), 360-36I. 
eral description of a broad collection of people. She refines it, however, by adding particular qualities: "I will use 'elite' to designate the trans-empire group identity evolving in the early empire of persons bound together by ties of privilege, education, culture, and connections with the imperial center and by the shared selfidentity these ties constituted" $(5) .^{3}$

With this definition in hand, Perkins turns to the sources, especially the Greek novels (by Chariton, Xenophon of Ephesus, Achilles Tatius, and Heliodorus) and the political writings (by Plutarch, Dio Chrysostomus, and Aelius Aristides) of the first and second centuries A.D., favored by members of the elite. However, her analysis of the local elites, like that of many other scholars, remains at an abstract level. Perkins gives examples of individuals playing particular social roles in the novels, but she does not fully relate them to the actual network of elite relations that undoubtedly involved, at least in some cases, imperial officials or even the emperor. Her focus on such themes as "cultural" and "cosmopolitan" identities and the functioning of the human body in the ancient world provides valuable information about how elites and Christians collectively dealt with Roman society, and vice versa, but the relationships and experiences of people in the real world are missing (I-2; I7-44, 62-89, for analyses of the Greek novels and the political writings).

Perkins' work illustrates a key problem in the study of local elites in the Roman Empire, as well as elites in many other empires and societies - the difficulty of integrating conceptual analysis with an examination of actual individuals. Furthermore, Perkins' definition of elites implicates many other complex termssuch as power, wealth, status, education, and network - that stand in need of explication. In 2008, Ruffini presented a study of social networks in Byzantine Egypt, mainly those of Oxyrhynchus and Aphrodito, that employed the traditional prosopographical approach to the sources but also made use of social-network analysis. As Ruffini and others have demonstrated, network analysis can both confirm what ancient historians already suspected and offer new insights. ${ }^{4}$

3 Peter Garnsey, Social Status and Legal Privilege in the Roman Empire (New York, 1970).

4 Giovanni Ruffini, Social Networks in Byzantine Egypt (New York, 2008), which explicitly states why social-network analysis, a tool frequently used in sociology and cultural anthropology, can be an asset to the study of ancient history ( $\mathrm{I}-40)$. See also Irad Malkin, Christy 
Scholars of the Roman Empire have been interested in the exercise of power for many decades. A better understanding of the power wielded by the Roman government-particularly the emperor and his household - is crucial to the understanding of the Empire. Yet, an analysis of the power structure at the local level in the cities of the Empire is equally important, though much of its success depends on the methodology employed to investigate it. The complexities surrounding positions of local power are not easily exposed. Modern scholars call attention to the multiple identities and different social personae that characterize members of the upper classes in Roman cities. To disentangle them requires uncommon depth and subtlety. ${ }^{5}$

The use of theories and models to analyze power is relatively

Constantakopoulou, and Katerina Panagopoulou (eds.), Greek and Roman Networks in the Mediterranean (New York, 2009).

5 For studies about individual emperors or emperorship as an institution, the perception and reality of power, representations and images of power, the imperial cult, and the position and force of the Roman army, see David Shotter, Augustus Caesar (London, I99I); Werner Eck, The Age of Augustus (New York, 2003); Ted Champlin, Nero (Cambridge, Mass., 2003); Anthony Birley, Hadrian: The Restless Emperor (London, I997); idem, Septimius Severus: The African Emperor (London, I988; orig. pub. I97I); Olivier Hekster, Commodus: An Emperor at the Crossroads (Amsterdam, 2002); Fergus Millar, The Emperor in the Roman World (London, I992; orig. pub. I977); Paul Zanker, Augustus und die Macht der Bilder (Munich, I987); Brian Campbell, The Emperor and the Roman Army, 31 BC-AD 235 (New York, I984); Simon Price, Rituals and Power: The Roman Imperial Cult in Asia Minor (New York, I984); Duncan Fiswick, The Imperial Cult in the Latin West: Studies in the Ruler Cult of the Western Provincies of the Roman Empire (Leiden, 1987-2005), 3v.; Ando, Imperial Ideology and Provincial Loyalty in the Roman Empire (Berkeley, 200o); Lukas de Blois et al. (eds.), The Representation and Perception of Roman Imperial Power: Proceedings of the Third Workshop of the International Network Impact of Empire (Roman Empire, c. 200 B.C.-A.D. 476) (Amsterdam, 2003).

Matthias Haake, "Philosopher and Priest: The Image of the Intellectual and the Social Practice of the Elites in the Eastern Roman Empire (First-Third Centuries AD)," in Beate Dignas and Kai Trampedach (eds.), Practioners of the Divine: Greek Priests and Religious Officials from Homer to Heliodorus (Cambridge, Mass., 2008), I45-I66. See also Sinclair Bell and Inge Hansen, Role Models in the Roman World: Identity and Assimilation (Ann Arbor, 2008), I-40, for the use of terms such as identity. Status is intertwinably linked to power. As Moses Finley, The Ancient Economy (London, I985), stated, status is an "admirably vague word with a considerable psychological element (5I)." According to Nicolas Purcell, "The Apparitores: A Study In Social Mobility," Papers of the British School at Rome, LI (I983), "Status varied enormously depending on the observer and on the place"; "Almost no boundary between social groups was impervious to the power of personal patronage of the effects of economic success" (I26). A person who was well-respected in his own community might have been absolutely undistinguished in Rome. Trimalchio in the Satyricon by Petronius (first century A.D.) exemplifies the vagaries of status. Among his fellow freedmen, he could almost be considered the princeps (leader), whereas outside that circle, he was a freedman with low status. See Hopkins, "Élite Mobility in the Roman Empire," Past \& Present, 32 (I965), I 2-26, for several criteria regarding status - wealth, birth, formal education, learned skill, ability, achievement, and style of life. 
new in the field of ancient history and, as stated above, fraught with controversy about the level of abstraction often involved. Mann's sociological theory of power, as given in the two volumes of The Sources of Social Power, is a case in point, given the polarized reaction to it. Hall and Schroeder's An Anatomy of Power, which contains sixteen contributions by leading sociologists who critically assess Mann's theories, as well as a response by Mann himself, testifies to the sociological significance of Mann's work during the past twenty years. ${ }^{6}$

Mann argues that all societies are analyzable by way of his socalled IEMP model, the components of which are named after four sources of social power-ideological (I), economic (E), military $(\mathrm{M})$, and political (P). His inclusion of military power as equal to the other three, instead of as subordinate to political power, has found its critics among other sociologists. Mann anchors his theory of social power, which stands in the traditions of Marx, Weber, and Durkheim, in his view of societies as organized networks. The guiding idea is that no one ever lives in isolation, and those in power are always dependent on a network to sustain their positions. In Mann's words, "Societies are constituted of multiple overlapping and intersecting networks of social power." Thus, each of the IEMP dimensions is to be regarded as a social network in itself. Power, in this model, is never free-floating; it cannot be treated merely as an abstraction. Collins, in his discussion of Mann's model, described the networks as "real connections among people, empirically observable as to where they spread out in space. It is always possible, in principle, to examine the shape of a network of power: ideological power, for example, is not simply at one time in history the workings of religious beliefs, but has a structure of priests, monks, missionaries, people participating in religious ceremonies."

6 Michael Mann, The Sources of Social Power. I. A History of Power from the Beginning to 1760 AD (New York, I986); II. The Rise of Classes and Nation-States (New York, I993) (volume III is supposedly underway). James Blaut, Eight Eurocentric Historians (New York, 2000), I26, nn. 2-4, calls Mann's second volume more solid in terms of evidence and theory. See also the review by Jeffrey Cormier in the Canadian Journal of Sociology Online (2006), at http:// www.cjsonline.ca/reviews/anatomypower.html, which calls attention to a question first asked by John Hall, "Political Questions," in idem and Ralph Schroeder (eds.), Anatomy of Power: The Social Theory of Michael Mann (New York, 2006), 52, n. 3-whether Mann is a sociological theorist or an analytical historian. See also Gianfranco Poggi, Forms of Power (New York, 200I); John Scott, Power (New York, 200I).

7 Karl Marx, Das Kapital (Hamburg, I867-I894); Max Weber, Wirtschaft und Gesellschaft: Grundriss der verstehenden Soziologie (Tübingen, 1956, orig. pub. I922); Émile Durkheim, De la 
Although Mann's first volume of The Sources of Social Power delves into such ancient societies as the Phoenicians, Greeks, Persians, and Romans, his analysis remains at the macro-level, concentrating on the grand themes of trade, military and naval power, imperialism, the phenomenon of slavery, and leadership. Moreover, his claim for the universality of the IEMP model does not extend to the micro-level of individuals. Opponents argue that the IEMP model would be useful for the study of local elites only if it did. In that way, it could appeal to both sociologists and ancient historians, offering sociologists a refinement of Mann's model for use at the micro-level in Roman society (as well as in other societies), and ancient historians, particularly the traditionalists, a demonstration of how Mann's model could be valuable for an examination of local power structures in cities of the Roman Empire. ${ }^{8}$

LOCAL POWER STRUCTURES The concept of power needs to be defined in the context of Roman cities before the IEMP model can be applied to the local elites. Both Mann's and Weber's ideas about power provide a valuable framework for understanding local relations of power in this setting. Although sociologists have had much to say about power, they do not appear to agree on its definition. Many modern scholars follow Weber, who identified power as "the capacity of a person within a social relationship to impose his will." Mann betrays Weber's influence when claiming, "In its most general sense, power is the ability to pursue and attain goals through mastery of one's environment." His restriction of the definition of power to social relations is also redolent of Weber. ${ }^{9}$

Even though Mann placed himself squarely in the Weberian

division du travail social (Paris, I893). Randall Collins, "Mann's Transformations of the Classic Sociological Traditions," in Hall and Schroeder (eds.), Anatomy of Power, 22. For criticism of Mann's inclusion of military power, see Poggi, "Political Power Un-manned: A Defence of the Holy Trinity from Mann's Military Attack," ibid., I35-I49. For Mann's standing in the tradition of Marx, Weber, and Durkheim, see Mann, History of Power, 4; Poggi, Forms of Power, 8-I4; for Mann's ideas about social networks, Mann, History of Power, 2, 4-6, 27; for Mann's advancements in his theory of state formation and comments on his view of social networks, Jack A. Goldstone, "A Historical, Not Comparative, Method: Breakthroughs and Limitations in the Theory and Methodology of Michael Mann's Analysis of Power," in Hall and Schroeder (eds.), Anatomy of Power, 263-264.

8 See Blaut, Eurocentric Historians, I I 4-I I6, for criticism of Mann's "peculiar theory about the role of Greece in the process."

9 Weber, Wirtschaft und Gesellschaft (Tübingen, I972; orig. pub. I922), 53 I. See also the review by Carlos Noreña of Oliver Hekster and Richard Fowler, Imaginery Kings: Royal Images 
tradition, he is careful to make a sharp distinction between "distributive" and "collective" power. Distributive power refers to A's ability to dominate B. For B to gain ground, A must lose ground; their relationship is a "zero-sum game" with a fixed amount of power. Collective power denotes a situation in which "persons in cooperation can enhance their joint power over third parties or over nature." $" 10$

Always unevenly distributed, power implies both control and obedience. People accept the rule of others for numerous reasons. Regarding Roman society, Ando argued-in Weberian fashionthat "submission to magistrates with access to coercive force need not be motivated by faith in a regime's legitimacy. Loyalism, like all behaviors, can be simulated, by individuals or groups, from opportunism, calculated self-interest, or sheer helplessness." Presumably, those who accepted the dominance of local elites enjoyed the benefits of their obedience, wheareas the local elites who obeyed the emperor and his representatives may well have behaved according to calculated self-interest. Power at the local level was certainly not isolated from power at the provincial or imperial level in the Roman Empire. Decisions and actions taken in the upper reaches of authority had an effect on the local level. ${ }^{11}$

THE IEMP MODEL APPLIED TO LOCAL ELITES In what ways are Mann's ideological, economic, military, and political power observable in the ancient world, particularly the cities of the Roman Empire? In Mann's words, political power "derives from the usefulness of centralized, institutionalized, territorialized regulation of many aspects of social relations." The members of the local city

in the Ancient Near East, Greece and Rome (Stuttgart, 2005), in Bryn Mawr Classical Review (2006.07.06), at http://bmcr.brynmawr.edu/2006/2006-07-06.html. For definitions of power, see Mann, History of Power, 6; Poggi, Forms of Power, I-2; for further discussion, Steven Lukes, Power: A Radical View (London, I974); Dietrich Rueschemeyer, Power and the Division of Labour (New York, 1986); Barry Barnes, The Nature of Power (New York, I988); Dennis Wrong, Power: Its Forms, Bases, and Uses (Chicago, I988; orig. pub. 1979); Stewart Clegg, Frameworks of Power (London, 1989); Scott, Power.

Io Mann bases this distinction on Talcott Parsons, Structure and Process in Modern Societies (New York, I960), I99-225. See Mann, History of Power, 6-7; Philip S. Gorski, "Mann's Theory of Ideological Power: Sources, Applications and Elaborations," in Hall and Schroeder (eds.), Anatomy of Power, I02-IO3.

I I Stanley Rothman, "Political Elite: Recruitment And Careers," International Encyclopedia of Social \& Behavioral Sciences (2004), I I656-I I66I(on control and obedience); Ando, Imperial Ideology, 374; Mann, History of Power, 8 (on authoritative power that "comprises definite commands and conscious obedience"). 
councils who regulated community activity had the most obvious political power. The military variety, which concerned matters of life and death, physical defense, and the survival of society, did not much devolve to the local elites in the cities, unless they had enjoyed military careers in the high echelons of the Roman army. Unlike Weberians and Marxists, Mann treats military power as distinct from, rather than as subsumed by, political power, arguing that "political powers are those of centralized, institutionalized, territorial regulation; military powers are of organized physical force wherever they are organized." To Mann, military power could well lie outside the social group that possessed political power. In the Roman world, however, to the extent that military force helped to consolidate the authority of the emperor, it was certainly subordinate to political power, especially since the emperor was the supreme commander of the military forces. But such was not the case throughout Roman history. In the third century A.D., for example, legions appointed emperors, occasionally even more than one at a time, without any involvement of the political sphere.

The increased militarization of the imperial government in the third century fits Mann's scheme perfectly. Scholars of the ancient world increasingly acknowledge the importance of the military as a separate force. Brown, for one, recognized the necessity of including military power as the missing piece in "a full understanding" of the elites of late antiquity. According to him, scholars tended to miss this point because their literary source material focuses too heavily on the civilian elite, whereas "the culture of the strong, silent men, the viri militares [military men], who formed a parallel elite at court and in the provinces, does not yield itself so easily to us." 12

In Mann's IEMP model, economic power reflects society's

I2 Mann, History of Power, 25-26 (on military and political power), I I (the argument for separation of military and polical power); Schroeder, "Introduction: The IEMP Model and Its Critics," in Hall and idem (eds.), Anatomy of Power, I. Alan Bowman, The Town Councils of Roman Egypt (Toronto, I97I); Vittinghoff, Europäische Wirtschafts- und Sozialgeschichte, 204-205, 223-224, 250-25I; Henrik Mouritsen, "The Album from Canusium and the Town Councils of Roman Italy," Chiron, XXVIII (I998), 228-254; for functions in the local city council, Harry Pleket, "Political Culture and Political Practice in the Cities of Asia Minor in the Roman Empire," in W. Schuller (ed.), Politische Theorie und Praxis im Altertum (Darmstadt, I998), 204-2I6. For the age of the "Soldatenkaiser," A.D. 235 to 284, see Klaus-Peter Johne and Udo Hartmann (eds.), Die Zeit der Soldatenkaiser: Krise und Transformation des Römischen Reiches im 3. Jahrhundert n.Chr. (235-284) (Berlin, 2008); for the position of legions within Roman society, 
need to meet its subsistence requirements through "the social organization of the extraction, transformation, distribution, and consumption of the objects of nature." Hence, in the Roman world, local elites with access to resources and/or food production-those with large estates - tended to possess it. However, the economic power of local elites went further than control over resources. Wealth was considered one of the criteria for fulfilling local magistracies. Economic dominance was also expressed through donations and benefactions to the community. ${ }^{13}$

Ideological power is the most complex of the four power types. At its basis stands the idea that if a social order is to persist for any length of time, norms and a shared ethos are essential. As Mann explained, "An ideological movement that increases the mutual trust and collective morale of a group may enhance their collective powers and be rewarded with more passionate adherence." Mann sees Christianity as exemplary in this respect. The ritual practices of the ancient religious traditions and cults are obvious expressions of ideological power, and the importance of rituals is a well-known feature of Roman communities. But Roman society contained many other expressions of ideological power,

Ramsey MacMullen, "The Legion as a Society," Historia, XXXIII (I984), 440-456; De Blois, The Policy of the Emperor Gallienus (Leiden, I976), 83-86; Michel Christol, "Armée et société politique dans l'empire romain au IIIe siècle ap. J.-C. (de l'époque sévérienne au début de l'époque constantinienne)," Civiltà Classica e Cristiana, IX (I988), I69-204; for arguments against the use of the terminology and concept of "militarization," Peter Eich, Zur Metamorphose des politischen Systems in der römischen Kaiserzeit: Die Entstehung einer"personalen Bürokratie" im langen dritten Jahrhundert (Berlin, 2005), 362-369; Peter Brown, "The Study of Elites in Late Antiquity," Arethusa, XXXIII (2000), 333.

I3 Mann, History of Power, 24. The lack of sources makes it difficult to establish the requisite wealth needed to be a city councilor. Furthermore, regulations differed from city to city. Pliny the Younger implies that in the early second century, a man needed about one-tenth of the minimum property qualification of a senator, which was I,000,000 sesterces, to be eligible for membership in a town council: "By the census you have I00.000 sesterces, which satisfactorily indicates that you are a town-councillor of Comum. Therefore, so that we not only make use of you as a town-councillor but also as an eques, I want to give you another 300.000 to make up your qualification for the equestrian order" (Pliny, Epistula I.I9). See Arnold H. M. Jones, The Later Roman Empire 284-602 (Baltimore, I964), 738-739; Richard DuncanJones, The Economy of the Roman Empire: Quantitative Studies (New York, I982; orig. pub. I974), I7-32, 243; Richard Talbert, The Senate of Imperial Rome (Princeton, I984), 48-53; Friedemann Quaß, Die Honoratiorenschicht in den Städten des griechischen Ostens (Stuttgart, I993), 343, 383; Pleket, Political Culture, 206; Vittinghof, Europäische Wirtschafts- und Sozialgeschichte, 200; Benet Salway, "Prefects, Patroni and Decurions: A New Perspective on the Album of Canusium," in Alison Cooley (ed.), The Epigraphic Landscape of Roman Italy (London, 2000), I I 5-I7I. 
such as the imperial ideology promulgated by the Roman emperors to legitimize their authority. ${ }^{14}$

Although the four components of social power are presented individually, they should not be regarded as isolated from each other; analysis demonstrates that they were often inextricably connected. Men with political power usually had a certain level of economic power (although the reverse was not always true). One person's position of command might have overlapped with several other sources of power.

Given that the sources of power were linked to each other, were they arranged in a hierarchy, or were they equally important? People with political power needed economic resources to finance their political careers. However, not everyone with economic power either desired political office or could achieve it. For one thing, the number of city councilors in Roman cities was always limited; wealth alone could not guarantee participation. Was political power regarded as more important than economic power? Mann's idea that distributive power came in fixed amounts implies that it was quantifiable, but on what scale? What measure of ideological, economic, and political (leaving aside military for the moment) power can be assigned to a local city councilor? Evidently, this problem is a stumbling block for any analysis of power. A quantitative analysis of the power relations within social networks would greatly enhance our understanding of interlocking community structures, but what form would it take? ${ }^{15}$

As an experiment, envision the following four individuals who might have inhabited any number of cities in the Empire: (I) a local personage wealthy enough to be a city councilor and prestigious enough as a religious cult leader to wield considerable

I4 Ideological power is based on several interrelated arguments within sociological traditions. Some sociologists prefer to speak of cultural power. See Schroeder, "Introduction," 45; Gorski, "Mann's Theory," Io4; Mann, "The Sources of Social Power Revisited: A Response to Criticism," in Hall and Schroeder (eds.), Anatomy of Power, 344-350, where he defends his choice for the use of the term ideological instead of cultural; idem, History of Power, 22. For a recent analysis of rituals in Roman communities, see Ando, The Matter of the Gods: Religion and the Empire (Berkeley, 2008); on imperial ideology, idem, Imperial Ideology; De Blois et al., Representation and Perception.

I5 Laurens Tacoma, Fragile Hierarchies: The Urban Elites of Third Century Roman Egypt (Leiden, 2006), discovered a substantial group of wealthy businessmen who were apparently excluded from politics. See also Pliny, Epistula IO. I I2; Vittinghoff, Europäische Wirtschafts- und Sozialgeschichte, 204-205; 223-224; 250-25 I; Gerd Theissen, "The Social Structure of Pauline Communities: Some Critical Remarks on J. J. Meggitt, Paul, Poverty and Survival," Journal for the Study of the New Testament, LXXXIV (200I), 67-68; Mann, History of Power, 6. 
Table 1 Hypothetical Schematic of the Four Sources of Social Power

\begin{tabular}{lllll}
\hline & I & E & M & P \\
\hline Local city councilor & yes & yes & no & yes \\
President, local city council & no & yes & no & yes \\
Eques, military career & no & yes & yes & yes \\
Senator, at the local level & no & yes & no & yes \\
\hline
\end{tabular}

ideological power; (2) a city-council president with even more wealth and political power than his fellow councilors and a degree of ideological power, derived from association with the city's official religious rites, but not so much as that of the cult leader above; (3) an eques (horseman or knight) with more wealth than a city councilor and a high level of military power (at least during his term of service), with at least a modicum of political power; and (4) a senator with the greatest amount of wealth and political power in the community, gained not so much from involvement in local magistracies and local government as from direct contact with the imperial court. Table I relates these four hypothetical dignitaries schematically.

The schematic cannot illustrate how power structures worked, because it does not give any indication of relative power levels. It might even give the false impression that the regular city councilor and the eques were the most powerful members of the community, since they possessed the most types of power. The only accurate way to assess individuals' power is via their relationships - that is, through social networks-preferably over time, since people tended to undergo both upward and downward mobility in their public careers. But even studies of individuals' relationships that are confined to one time and place require data about relative levels of power. Unfortunately, the evidence about upper-class individuals in the ancient world is often scarce and temporally inexact.

THE MODEL OF MANN AND ANCIENT MAN Clearly, an analysis based on the IEMP model must improve on the hypothetical schematic above to shed light on the details of local power structures. It must do justice to the relationships between ordinary members of the local elites (such as members of the city councils) and those luminaries not necessarily born in the area where they resided 
(such as senators who retired to a particular town, equites, or imperial officials) but influential there nonetheless.

The senators, equestrians, and other dignitaries who owned estates at the local level, and frequently had only a sporadic presence within a community, comprised what might be called a supra-local elite. The main evidence for them comes from thousands of inscriptions throughout the empire that hint at their power, such as one that honored Gaius Valerius Marinus in early third-century Tridentum: "To Gaius Valerius Marinus, son of Gaius Valerius from the tribe Papiria, after he had obtained all magistracies in Tridentum, flamen of Roma and Augustus, prefect quinquennalis, augur, chosen for the annona of the legion III Italica, sodalis of the holy rites of Tusculum, selected as judge in three decuriae, decurion of Brixia, curator rei publicae of Mantua, with the equestrian status, prefect of the fabri, patron of the colonia by public decree." 16

After having held all standard magistracies in Tridentum, Valerius became active in a larger arena. In terms of Mann's model, Valerius had political power. Valerius had also been chosen to take care of provisions (annona) and his service as a local prefect would have given him authority over the local fire brigade. He also acted as a priest (flamen) in the cult of Rome and Augustus, an augur, and a sodalis in the holy rites of Tusculum - all signs of the ideological power conferred by religious distinction. Finally, as an honorary patron of Tridentum, he had economic power as well.

The inscription raises many questions about Valerius' background. Did he come from an equestrian family, or did he obtain this status later in life? What type of influence did he exercise in Tridentum, Brixia, and Mantua? One of the problems with honorary inscriptions, which constitute a large part of the evidence about the Empire's elite, concerns their very character as "honorary." They provide a listing of offices but little about the exercise

I6 For a discussion of the inscription's date, see Theodor Mommsen (ed.), Corpus Inscriptionum Latinarum (CIL) (Berlin, I872), 5.5036 (Mommsen's comments on 53I); Denis van Berchem,"L'annone militaire dans l'empire romain au IIIe siècle," Mémoires de la Société nationale des antiquaires de France, X (I937), I 17-202, esp. I5 I; Fritz Mitthof, Annona Militaris: Die Heeresversorung im spätantiken Ägypten: Ein Beitrag zur Verwaltungs- und Heeresgschichte des Römischen Reiches im 3. bis 6. Jh. n. Chr. (Florence, 200I), 75, n. I73. A praefectus quinquennalis was part of the local government - a member of the local council and patronus of the fire brigade - in the cities of the Roman Empire and appointed as substitute for the emperor or a member of the imperial family who were elected into the highest local magistracy (that of duovir) but who would never in reality take up that office. 
of power at the local level or about relationships between members of the elite. A genuine sense of Valerius' position requires a close look at the cities and region where he was active and a comparison of the evidence about him with that of other contemporary members of the elite. As situated within the IEMP model, Valerius' possession of three of the four sources of social power should be an indication of high status and considerable influence in the region. But the discovery of others in the same locale who fell into one or more of the IEMP categories would help to further our sense of local, and even regional, relations of power.

Valerius exemplifies thousands of individuals named on inscriptions who cannot be linked to a specific date or to a larger network. A better approach to how individuals contributed to a local power structure might be to perform an intensive case study of an entire city or area that produced multiple inscriptions and other literary artifacts. In Aphrodisias, for example, inscriptional evidence from approximately A.D. Ioo to 300 reveals about 200 men and women who were participants in the local power structures - members of the local and supra-local elite. Entering these individuals into a database would not only enable a detailed mapping of their various sources of power but also possibly lead to the discovery of the networks in which they operated. ${ }^{17}$

In addition to the use of traditional prosopographical methods to detect the individuals that comprised the local elite of Aphrodisias, Mann's IEMP dimensions permit a more "neutral" exploration of the ancient evidence by describing the sources of power without recourse to the traditional boundaries between, or definitions of, local people that might diminish the scope of the find-

I7 Ongoing large-scale excavations at the site, started by Kenan Erimin in I962 and now under the direction of Christopher Ratté and Bert Smith, have resulted in numerous publications: for example, the Aphrodisias Papers I, II, III, and IV (I990-2008), in the Journal of Roman Archaeology supplements; several contributions by Ratté and Smith in American Journal of Archaeology: XCIX-CII (I995-I998), CIV (2000), CVIII (2004), CXII (2008); Joyce Reynolds, Aphrodisias and Rome (London, 1982); Erim, Aphrodisias: City of Venus Aphrodite (London, I986); Charlotte Roueché, Aphrodisias in Late Antiquity (London, I989); idem, Performers and Partisans at Aphrodisias in the Roman and Late Roman Periods (London, I993); Angelos Chaniotis, "New Inscriptions from Aphrodisias (I995-200I)," American Journal of Archaeology, CVIII (2004), 377-4I6. The individuals examined are based largely on Smith (ed.), Aphrodisias II: Roman Portrait Statuary from Aphrodisias (Mainz am Rhein, 2006), 77-96; Chaniotis, New inscriptions. Many inscriptions link generations of family members and families to other families through marriages. For instance, the family of Adrastos Hierax was obviously prominent in Aphrodisias from the first through the third centuries (ibid., 4I I), and in the second century, the senatorial family of the Carminii, probably ran in the the same small inner circle as the Hierax (ibid., 387-388). 
ings. There may well have been a broader set of people in positions of power and influence-of "dissonant status" as they might be called-who did not ostensibly inhabit a community's politically powerful inner circle. For instance, Tacoma's study of urban elites in third-century Egypt revealed a substantial group of businessmen who were just as wealthy as city councilors but who were apparently excluded from politics. His study discovered a relatively small core group within each urban elite that remained consistent during long periods of time but did not preclude newcomers to their periphery from the "regular urban population, more specifically among the landowners directly below the elite." In this reconstruction, once-elite families outside the core group who were on a downward spiral frequently reverted to non-elite status, to be replaced by new, up-and-coming families. The economic-power dimension within the IEMP model would acknowledge the power that these socially mobile men had within their communities. It would also recognize the power of wealthy women with large estates, who sometimes were great benefactors to their communities, though political power was beyond their ken. $^{18}$

Another group in this extended elite were the numerous liberti (freedmen) who belonged to supra-local potentes (groups of powerful people) and who were (economically) influential in their community. For example, more than twenty inscriptions dating to the early second century, mostly from Barcino, honor Lucius Licinius Secundus, the libertus of the senator Lucius Licinius Sura,

I 8 See Lothar Wierschowski, Die regionale Mobilität in Gallien nach den Inschriften des 1. bis 3. Jahrhundert n. Chr. (Stuttgart, I995), 22 I, which argues that the "Oberschichten" group included more people than just those decurions with political power. Wierschowski limits his scope to equites and seviri (custodians of cults). See Theisssen, "Social Structure in Pauline Communities," 67, n. 8, 73, which discusses dissonant status, based on Vittinghof, Europäische Wirtschafts- und Sozialgeschichte, 205. Tacoma, Fragile Hierarchies, writes, "It is much easier to seek the new entrants in the layers of society directly beneath the elite of landowners: among those people with landholdings just below the minimum requirement for elite entrance. It is to this group that discontinuous elite families reverted, and it is in this group that social risers should be sought. No social stigma attached to their rise because they belonged essentially to the same milieu, and shared the same ideology" (264). A good example of a woman with a large estate is Apollonis, who was honored posthumously at the beginning of the first century A.D. in Kyzikos, Asia Minor. Reactions to her death and the composition of her funeral procession are clear indications of her influence within the community. See Riet van Bremen, The Limits of Participation: Women and Civic Life in the Greek East and the Hellenistic and Roman Periods (Amsterdam, I996), I-3, 47-54 (on the legal context within which women sponsored munera, honores, and priesthoods); Emily Hemelrijk, "City Patronesses in the Roman Empire," Historia, LIII (2004), 209-245. 
who had been a close friend of the emperor Trajan. Other liberti who might have played an important part in communities were those who became Augustales (priests in the cult of Augustus). As Patterson argues, Augustales, who had clear advantages over the masses, were often crucial to the successful functioning of the cities. Finally, freedmen who rose to the status of imperial procurator, (financial agent and administrator) could be important locally when stationed in the provinces. The IEMP model would undoubtedly acknowledge the power of these people, even though the traditional approach might not include them within local elites. ${ }^{19}$

Mann's IEMP model can be an effective instrument in an analysis of the various, interrelated aspects of an individual's power. The fact that it cannot assign absolute numbers to levels of power should not detract from its value. As shown, its neutral picture of local power dynamics is more comprehensive than that created by traditional methods, though much work remains to be done to facilitate its application at the micro-level of the individual. This review essay is intended to encourage discussion about how to approach elites in a way that draws as much information as possible about local power networks in the Roman Empire, leaving behind, and reconciling, the tired conflict between traditional and more modern methodologies. ${ }^{20}$

I9 For the dossier of Lucius Licinius Secundus, see André Chastagnol, Marcel Le Glay, and Patrick Le Roux (eds.), Année épigraphique (AE) (Paris, I98I), 569; Alfred Merlin (ed.), AE (I957), 26; Georges Fabre, Marc Mayer, and Isabel Rodà (eds.), Inscriptions Romaines de Catalogne (IRC) (Paris, I997), IV, 4.IOO; CIL 2.4536-48; 2.6I48 (IRC 4.IOI); 2.6I48c-d (IRC 4.86-87); 2.6I49 (IRC 4.95); Hispania Epigraphica (HE) 7.I82-83 (http://eda-bea.es/); IRC 4.88; IRC 4.IOO, IRC 4.IO2-IO3; IRC I.I25. See also Alföldy, "Die Bildprogramme in den römischen Städten des Conventus Tarraconensis: das Zeugnis der Statuenpostamenta,” in Antonino Blanco et al. (eds.), Homenaje a Garcia y Bellido (Madrid, I979), IV, I77-275, esp. 222. Patterson, Landscape \& Cities: Rural Settlement and Civic Transformation in Early Imperial Italy (New York, 2006), 242-250. See Eck, "Elite und Leitbilder in der römischen Kaiserzeit," in Jürgen Dummer and Meinolf Vielberg (eds.), Leitbilder der Spätantike_Eliten und Leitbilder (Stuttgart, I999), 3 I-55, esp. 46-47, which mentions the case of T. Flavius Pergamus, who became the second-most powerful man in the province of Asia behind the equestrian procurator.

20 See James Manning, Land and Power in Ptolemaic Egypt: The Structure of Land Tenure (New York, 2003), which applies the IEMP model (misnamed as IMEP) to Ptolemaic Egypt. 
